\title{
Issues and Challenges in Short Food Supply Chains: A Systematic Literature Review
}

\author{
Bilgesu Bayir*(D), Aurélie Charles $\mathbb{D}$, Aicha Sekhari $(\mathbb{D})$ and Yacine Ouzrout $(\mathbb{D}$
}

Citation: Bayir, B.; Charles, A.; Sekhari, A.; Ouzrout, Y. Issues and Challenges in Short Food Supply Chains: A Systematic Literature Review. Sustainability 2022, 14, 3029. https://doi.org/10.3390/su14053029 Academic Editors: Riccardo Testa Giuseppina Migliore Giorgio Schifani and József Tóth

Received: 7 February 2022

Accepted: 1 March 2022

Published: 4 March 2022

Publisher's Note: MDPI stays neutral with regard to jurisdictional claims in published maps and institutional affiliations.

Copyright: (C) 2022 by the authors. Licensee MDPI, Basel, Switzerland. This article is an open access article distributed under the terms and conditions of the Creative Commons Attribution (CC BY) license (https:// creativecommons.org/licenses/by/ $4.0 /)$.
DISP-UR4570, University Lumiere Lyon 2, University of Lyon, 69676 Bron, France; a.charles@univ-lyon2.fr (A.C.); aicha.sekhari@univ-lyon2.fr (A.S.); yacine.ouzrout@univ-lyon2.fr (Y.O.)

* Correspondence: bilgesu.bayir@univ-lyon2.fr

\begin{abstract}
Consumers increasingly prefer more direct and more transparent food distribution channels, such as short food supply chains (SFSCs). Nonetheless, SFSCs face a variety of issues and challenges in their creation and functioning, resulting in limited performance and sustainability, as well as in difficulties of upscaling. This study aims at improving our understanding of SFSCs' issues/challenges through a systematic review of the most recent literature. We perform a full-text content analysis of 44 studies, looking for answers to the research questions: At which parts of the SFSCs do the issues/challenges occur? How can we characterize the issues/challenges in SFSCs? While doing so, we offer a holistic perspective on SFSCs. We make use of the SCOR model to define SFSC processes as well as to describe the nature of these issues/challenges. The findings of this study shed light on the nature and strategic-tactical-operational level of the issues/challenges in SFSCs and point out the limitations in the existing literature such as the SFSC processes that are neglected. The holistic approach we suggest and the insight on SFSCs' issues/challenges we provide can help researchers offer effective solutions and strategies to support the overall development of SFSCs.
\end{abstract}

Keywords: short food supply chain; alternative food network; local food system; sustainability; logistics processes; supply chain modeling; SCOR model

\section{Introduction}

\subsection{Motivations of the Study}

In recent years consumers' habits concerning food purchases have been changing due to a desire for healthy eating and sustainable consumption. Consumers who look for food products of high quality and well-known origins turn increasingly to more direct and more transparent supply chains (SCs). This trend further accelerated during the first year of the COVID-19 pandemic, leading to discussions about whether these alternative distribution channels can meet demand and improve food system resilience and sustainability. In this context, short food supply chains (SFSCs) respond to the demand of consumers for more proximity and quality, while providing small-scale producers an opportunity for autonomy and enhanced income.

The French Ministry of Agriculture, Food, and Forestry defines SFSCs as the "commercialization of agricultural products through direct selling or indirect selling when only one intermediary is involved" [1] (p. 198). According to this definition, even though the locality of the food and the minimized number of intermediaries make part of ideal-type SFSCs, these distribution channels are not limited to direct sales [2] or local food [3]. Similarly, SFSCs can be limited to organic products, but this is not always necessarily the case. Figure 1 below presents the scope of SFSCs as accepted in this study, with regard to directness, locality, and organic production.

SFSCs typically involve producers with limited production and logistics capacities. By participating in SFSCs, they find themselves suitable marketing channels that enable them to become entrepreneurs. Nevertheless, several studies argue that producers often cannot 
upscale their activity through short distribution channels [4-6] due to their limited access to markets and financial resources. In certain cases, the inability of SFSC stakeholders to upscale their production and distribution leads to a mismatch between demand and supply in the face of the escalating consumer demand for SFSC products. During lockdowns caused by the COVID-19 pandemic, for example, there was a peak in demand for SFSC products, and the producers needed to show great agility to handle the dramatic increase [7].

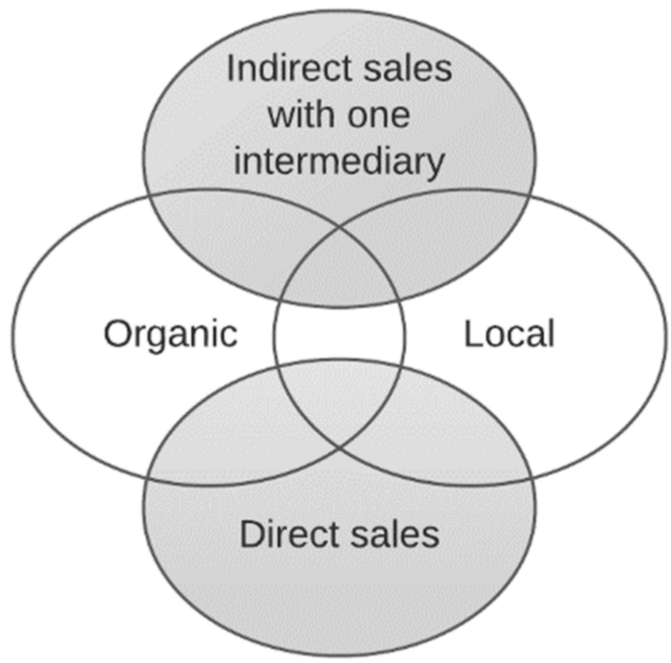

Figure 1. Scope of SFSCs as accepted in this study, represented by the regions highlighted in gray.

To satisfy the increasing demand and contribute to the creation of more sustainable and resilient food systems, SFSCs need to increase their overall impact [8]. To participate in SFSCs and expand their supply capacities, many active and potential stakeholders need the local, national, and supranational authorities to facilitate the access to infrastructure $[9,10]$ and financial resources [11,12] as well as to training [13] and networking opportunities [11]. Policymakers also play an important role in facilitating the functioning of SFSCs through policy reforms $[12,14,15]$. On the other hand, contributions of the scientific community are equally critical for identifying and overcoming the issues and challenges that complicate the establishment, performance improvement, and upscaling of SFSCs (i.e., increased production and/or logistics capacities, increased number of producers) [16,17]. Moreover, in our opinion, the novelty of SFSC initiatives adds to the importance of methodically studying these issues and challenges, since these recent initiatives often include insufficiently experienced practitioners and the lack of an established culture of scientific management and optimization, resulting in poor performance and impeding their upscaling.

\subsection{Originality of the Study}

Literature reviews about SFSCs focus on characterization [18], sustainability properties [19,20], and logistics [17] of SFSC, as well as on the coexistence of long and short FSCs [21]. To the best of our knowledge, however, a systematic review of the issues and challenges in SFSCs is not available yet in the scientific literature. This study, therefore, offers a systematic review of issues and challenges that SFSC stakeholders encounter during the creation and functioning of these initiatives.

Even though there is no such systematic review in the literature, many studies mention the existence and acknowledge the importance of SFSC issues and challenges such as costly distribution [22], distribution channel diversification [23], and use of digital technologies [3]. Nonetheless, these studies typically focus on one specific SC process or activity, particularly on production and distribution processes [24], without discussing the other parts of the SC. Moreover, most studies tend to adopt a one-dimensional perspective in their evaluation of SFSCs; some approach the subject of SFSCs from a purely social point of view, while some limit it to an optimization problem. In other words, the scientific research on SFSCs does not embrace a holistic approach, resulting in a lack of effective models and solutions to support 
the overall functioning and improvement of SFSCs. To overcome this limitation, we need to study SFSCs holistically by considering all the processes of SFSCs [17] and by embracing a multidimensional perspective (e.g., consideration of economic, social, environmental, and health-related aspects).

As a first step toward a holistic SFSC vision, we identify the main processes that compose an SFSC by benefiting from the SC processes defined in the supply chain operations reference (SCOR) model by the Association for Supply Chain Management. The use of the SCOR model and the definition of SFSC processes can help forge a link between the supply chain management field and SFSCs research, thus ensuring that we do not ignore any processes while aiming for performance improvement and upscaling. For the same purpose, we also define 12 issue/challenge (i/c) natures such as economic, optimization, social, and so on (see Section 2.2.1 for the complete list). Finally, we make use of strategic-tactical-operational levels to help characterize the issues and challenges encountered in SFSCs.

\subsection{Objective of the Study}

According to Pato [25], solving issues and minimizing difficulties in SFSCs require the participation not only of supply chain stakeholders but also of civil society organizations, public institutions, and scientific researchers. The contribution of this study, hence, is to provide these groups with a holistic approach to SFSC issues and challenges, contributing to the proposal of realistic and comprehensive solutions and strategies to support the performance improvement and upscaling of SFSCs. To improve our understanding of the issues and challenges that the SFSC stakeholders encounter, this study aims to answer the research questions (RQs) below in light of the existing scientific literature:

- $\quad$ RQ 1: At which parts of the SFSCs do the issues and challenges occur?

- RQ 2: How can we characterize the issues and challenges in SFSCs according to the SFSC processes that they relate to, $\mathrm{i} / \mathrm{c}$ natures, and the level of the solutions that they require?

To answer these questions, the remainder of the study is structured as follows: The Section 2 describes the steps of the study, including a general literature review and the systematic literature review on SFSC issues and challenges. The dimensions we defined to reach our results (SFSC processes, $\mathrm{i} / \mathrm{c}$ natures, and i/c levels) are also described in this section. Section 3 provides background information, particularly on the emergence and characteristics of SFSCs and includes a SWOT analysis as well as a thematic classification. Section 4 interprets the findings by making observations related to each research question. Finally, Section 5 summarizes our findings, states the limitations of the study, and provides perspectives for future research.

\section{Materials and Methods}

\subsection{Review of the SFSCs Literature}

We started our study with a broad review of the SFSCs literature. To complement our review with quantitative information, we also made a thematic classification of SFSC studies according to their focus: in other words, their main subject. In September 2020, out of the 474 studies we reached in the Scopus database that had been published since 2000 we identified 172 that directly handled SFSCs. (The search was cut off in 2000 since the first study to use the term SFSC was published that year [26]). We classified these studies according to their main interest, mainly based on their titles, author keywords, and abstracts. In this classification, we defined 26 themes such as emergence of SFSCs, characteristics of SFSCs, SC strategies, economic sustainability, and so on (see Section 3.3 for all the themes). Most studies were classified under more than one theme. The qualitative and quantitative results of this literature review are presented in Section 3. 


\subsection{Systematic Literature Review on SFSC Issues and Challenges}

Following our broad literature review, we identified the need for a more detailed review of the literature with a particular focus on the issues and challenges $(i / c)$ in SFSCs. To do so, we opted for a more systematic approach where we focused on the most recent publications, performed a full-text reading, and looked for particular information, namely SFSC issues and challenges $(\mathrm{i} / \mathrm{c})$. For this detailed literature review, we limited the timespan to 2020-2021 since we wanted to focus only on the most recent literature due to all the changes that have occurred in the sector, particularly the impact of the COVID-19 pandemic that increased the popularity of SFSCs among consumers and researchers. Among the 44 studies included in our review were three papers that were literature reviews $([17,20,21]$ in the reference list of the study). As a result, the impact of past research is still inherent in our study.

At the beginning of our systematic literature review of i/c in SFSCs, we made a keyword search in Web of Science database in September 2021, using the keyword string presented in Table 1. Later, we methodically selected the studies to include in our review as demonstrated in Figure 2. Among the 106 studies that were published in 2020 and 2021, five were eliminated after reading the abstracts since these studies were about sectors other than food (e.g., forest products), but they still appeared in the results due to keyword resemblance. Out of the 101 remaining studies, 57 were eliminated after full text browsing since they did not focus on SFSCs but rather mentioned them very briefly or only as an example.

Table 1. Keyword string used in Web of Science database.

\begin{tabular}{|c|c|c|c|c|}
\hline Title & & Abstract & & Author Keywords \\
\hline $\begin{array}{l}\text { "short * food * supply chain *" } \\
\text { OR } \\
\text { "short * agri-food * supply chain *" } \\
\text { OR } \\
\text { "short supply chain *" }\end{array}$ & OR & $\begin{array}{l}\text { "short * food * supply chain *" } \\
\text { OR } \\
\text { "short * agri-food * supply chain *" } \\
\text { OR } \\
(\text { "short* supply chain *" AND } \\
\text { ("agri *" OR "food *" OR "farm *")) }\end{array}$ & OR & $\begin{array}{l}\text { "short * food * supply chain *" } \\
\text { OR } \\
\text { "short * agri-food * supply chain *" } \\
\text { OR } \\
\text { "short supply chain *" }\end{array}$ \\
\hline
\end{tabular}

In Web of Science database, the asterisk $\left.{ }^{*}\right)$ represents any group of characters or no characters.

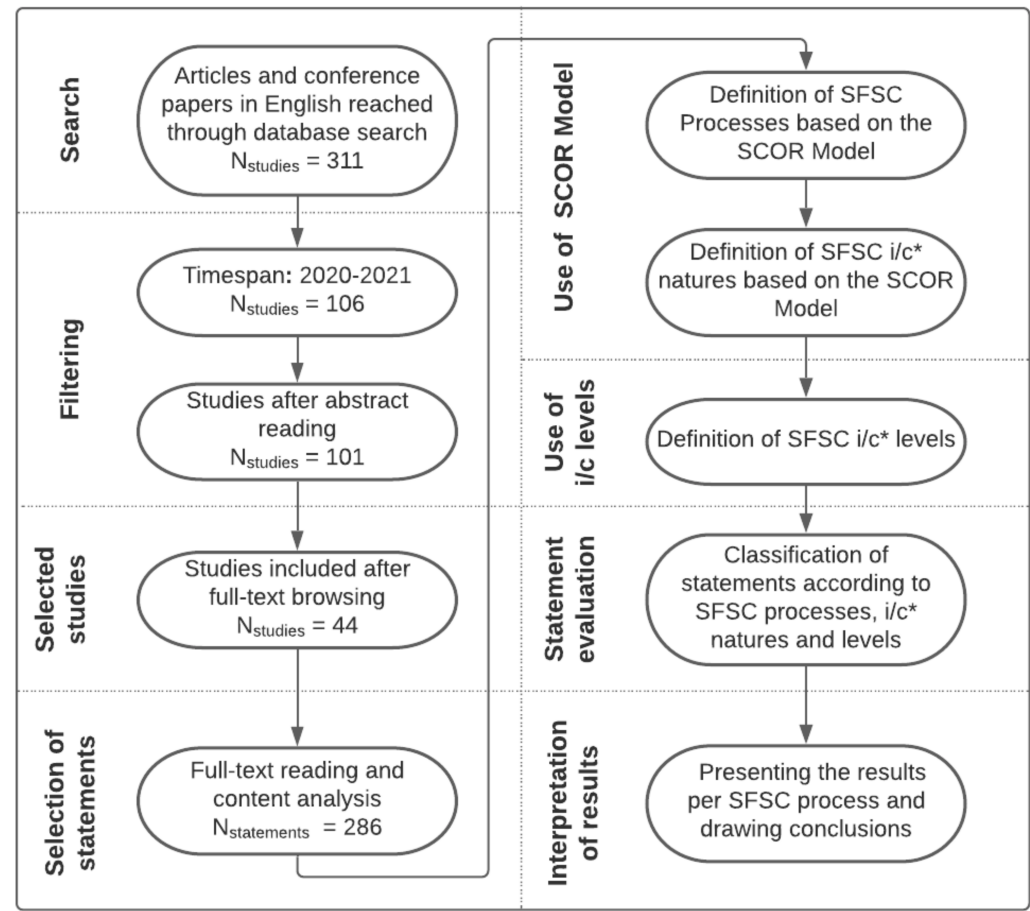

* Issue or challenge

Figure 2. Steps of the systematic literature review. 
During the full-text reading of the selected 44 studies, we looked for statements that pointed out the i/c that SFSC practitioners face. We opted for full-text reading since this information is not explicitly defined as "issue", "problem", "barrier", "success factor", or "challenge" most of the time, and it is often embedded in the text, requiring in-depth content analysis (see, for example [21] from the SFSC literature for another study that uses a similar content analysis method). As a result of the full-text content analysis, we reached $286 \mathrm{i} / \mathrm{c}$ statements that implied an i/c in SFSCs from the 44 selected studies. Concerning the identification of $i / c$, it is important to note that we considered only the statements that specifically concerned SFSCs and not any other similar concepts such as alternative food networks or local food systems.

\subsubsection{Definition of 3 Dimensions for SFSC i/c: SFSC Processes, i/c Natures, and i/c Levels}

Following the identification of relevant information in each selected study, we defined 3 dimensions to help us evaluate and interpret the selected i/c statements in a way to include every stage and every aspect of the SFSCs in our study.

To develop the definitions of the first two dimensions, SFSC processes and i/c natures, we used the SCOR model, proposed by the Supply Chain Council (APICS). The SCOR model is a comprehensive and well-known tool in the SCM domain that helps describe, analyze, and improve SCs by providing a methodology as well as benchmarking and diagnostic tools [27]. As displayed in Figure 3, the SCOR model proposes six main SC processes: "plan", "source", "make", "deliver", "return", and "enable".

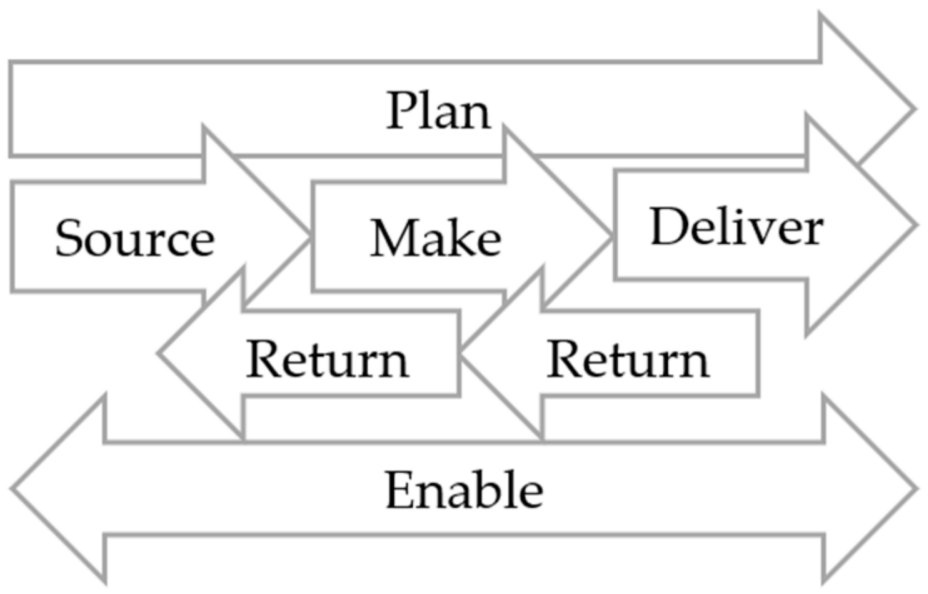

Figure 3. Six main processes in the SCOR model.

The processes, "source", "make", "deliver", and "return", refer to SC processes where material movement or transformation takes place, whereas the process, "plan", concerns determining the courses of action regarding these processes. On the other hand, the SCOR model includes a sixth far-reaching process, "enable", that is associated with the whole supply chain. "Enable" integrates processes such as human resources processes, financial processes, and ICT (information and communication technologies) processes with the supply chain processes [27]. Accordingly, we used the planning and execution processes defined in the SCOR model to propose SFSC processes (see Table 2), while we used "enable" for the definition of another dimension: $i / c$ natures (see Table 3). As per the identification of $\mathrm{i} / \mathrm{c}$ natures, we shared some keywords that describe the themes we frequently encountered in the selected studies in Table 4. 
Table 2. Definition of SFSC processes based on SCOR model processes.

\begin{tabular}{cc}
\hline SCOR Model Processes & SFSC Processes \\
\hline Plan & $\begin{array}{c}\text { Planning of agricultural production } \\
\text { Planning of food processing } \\
\text { Planning of logistics activities }\end{array}$ \\
\hline Source & Sourcing agricultural input \\
Sake & Agricultural production \\
& Food processing \\
\hline & $\begin{array}{c}\text { Product distribution: } \\
\text { Order management } \\
\text { Packaging }\end{array}$ \\
& Transportation \\
Deliver & Sales \\
& Consumption \\
& Waste management \\
& Storage \\
\hline Return & Reverse logistics \\
\hline
\end{tabular}

Table 3. Describing the nature of SFSC i/c based on the SCOR model process Enable.

\begin{tabular}{|c|c|}
\hline SCOR Model Process: Enable & i/c Natures \\
\hline Supply chain business rules & Optimization and resilience \\
\hline Supply chain risk & Upscaling and marketing \\
\hline Supply chain performance & Economic \\
\hline Supply chain procurement & Environmental \\
\hline \multirow{4}{*}{ Supply chain human resources } & Labor and competences \\
\hline & Social \\
\hline & Health-related \\
\hline & Culture- and habit-related \\
\hline Supply chain assets & Physical infrastructure \\
\hline $\begin{array}{l}\text { Supply chain contracts } \\
\text { Supply chain network }\end{array}$ & Cooperation, collaboration, and coordination \\
\hline Regulatory compliance & Political, bureaucratic, compliance \\
\hline $\begin{array}{l}\text { Data and information } \\
\text { Supply chain technology }\end{array}$ & Data, information, and technology \\
\hline
\end{tabular}

Concerning the definition of SFSC processes, below are some clarifications:

- We include "product distribution" as an umbrella process even though we already defined several processes within it. This is because many i/c statements we encountered were related to product distribution in a general sense and often the relevant process within product distribution (e.g., order management, storage) was not specified.

- We use "distribution", "logistics", and "transportation" in such a way to refer to different concepts and not interchangeably. Accordingly, logistics includes any activities relating to sourcing, product distribution, and reverse logistics, while transportation refers only to moving products using a vehicle.

- "Order management" concerns tracking, preparing, and shipping customer orders.

- "Sales" process represents when customers purchase the food products, for example by selecting products and paying for them in a farmers' market, or by placing an order online and paying by bank card.

- "Consumption" involves what comes after the sales process. In other words, it implies food preparation and consumption for consumers.

- "Waste management" consists of food and packaging material waste that occur during production distribution. 
Table 4. Some keywords for each class of i/c natures.

\begin{tabular}{|c|c|c|c|c|c|}
\hline $\begin{array}{l}\text { Optimization and } \\
\text { Resilience }\end{array}$ & $\begin{array}{c}\text { Data, Information, } \\
\text { and Technology }\end{array}$ & $\begin{array}{l}\text { Upscaling and } \\
\text { Marketing }\end{array}$ & $\begin{array}{l}\text { Labor and } \\
\text { Competences }\end{array}$ & $\begin{array}{c}\text { Physical } \\
\text { Infrastructure }\end{array}$ & $\begin{array}{l}\text { Cooperation, } \\
\text { Collaboration, } \\
\text { Coordination }\end{array}$ \\
\hline $\begin{array}{l}\text { Logistics efficiency } \\
\text { Small product } \\
\text { volumes } \\
\text { High distribution } \\
\text { costs } \\
\text { Delivery schedules } \\
\text { Harvest schedules } \\
\text { SC disruptions } \\
\text { Responding } \\
\text { rapidly to } \\
\text { changing } \\
\text { conditions } \\
\text { Joint planning }\end{array}$ & $\begin{array}{c}\text { Information about } \\
\text { products } \\
\text { Market } \\
\text { information } \\
\text { Data analytics } \\
\text { Digitalization } \\
\text { Online SFSCs } \\
\text { Smart technologies } \\
\text { Use of IT } \\
\text { Information } \\
\text { asymmetry } \\
\text { Customer } \\
\text { demands and } \\
\text { trends }\end{array}$ & $\begin{array}{c}\text { Product } \\
\text { diversification } \\
\text { Distribution } \\
\text { channel } \\
\text { diversification } \\
\text { Demand } \\
\text { Target clientele } \\
\text { High-quality } \\
\text { products } \\
\text { Public interest } \\
\text { Image, reputation } \\
\text { Certification, } \\
\text { labeling, branding } \\
\text { Promotion, } \\
\text { advertisement } \\
\text { Competition } \\
\text { Integrating new } \\
\text { participants } \\
\text { Niche market }\end{array}$ & $\begin{array}{l}\text { Knowledge } \\
\text { Skills } \\
\text { Experience } \\
\text { Creativity } \\
\text { Training, } \\
\text { education, } \\
\text { mentoring } \\
\text { Cross-learning } \\
\text { Expert advice } \\
\text { Small workforce } \\
\text { Qualified labor } \\
\text { Long working } \\
\text { hours } \\
\text { Volunteer work }\end{array}$ & $\begin{array}{c}\text { Using LFSC } \\
\text { infrastructure } \\
\text { Access to land } \\
\text { Access to transport } \\
\text { Processing } \\
\text { facilities } \\
\text { Points of sale } \\
\text { Internet } \\
\text { infrastructure } \\
\text { Food hubs, } \\
\text { collection centers } \\
\text { Electric vehicles } \\
\text { Refrigerated } \\
\text { vehicles } \\
\text { Storage areas }\end{array}$ & $\begin{array}{c}\text { Relationships with } \\
\text { other actors } \\
\text { Synergies } \\
\text { Shared interests } \\
\text { Sharing resources } \\
\text { Networks } \\
\text { Cooperatives } \\
\text { Building } \\
\text { communities } \\
\text { Volunteers } \\
\text { Communication } \\
\text { among } \\
\text { stakeholders } \\
\text { Joint decisions } \\
\text { Commitment } \\
\text { Risk sharing } \\
\text { Collective } \\
\text { knowledge }\end{array}$ \\
\hline Economic & Environmental & Social & Health-Related & $\begin{array}{l}\text { Culture- and } \\
\text { Habit-Related }\end{array}$ & $\begin{array}{c}\text { Political, } \\
\text { Bureaucratic, and } \\
\text { Compliance }\end{array}$ \\
\hline $\begin{array}{c}\text { Investment } \\
\text { Economies of scale } \\
\text { Cost accounting } \\
\text { Product pricing } \\
\text { Capital shortage } \\
\text { Price competition } \\
\text { Survival } \\
\text { Willingness to pay } \\
\text { Distribution costs } \\
\text { Wages } \\
\text { Subscription fees } \\
\text { for consumers }\end{array}$ & $\begin{array}{l}\text { Organic farming } \\
\text { Seasonality of } \\
\text { agriculture } \\
\text { Use of natural } \\
\text { resources } \\
\text { Eco-labels } \\
\text { Packaging } \\
\text { Waste }\end{array}$ & $\begin{array}{c}\text { Access of } \\
\text { low-income } \\
\text { consumers } \\
\text { Dedicated } \\
\text { customer groups } \\
\text { Face-to-face } \\
\text { interaction } \\
\text { Trust-based } \\
\text { relationships } \\
\text { Proximity relations } \\
\text { Conflict resolution } \\
\text { Fair prices } \\
\text { Communication } \\
\text { skills }\end{array}$ & $\begin{array}{c}\text { Organic products } \\
\text { Food quality } \\
\text { Quality assurance } \\
\text { systems } \\
\text { Food safety } \\
\text { Hygiene standards } \\
\text { Nutritional } \\
\text { recommendations } \\
\text { COVID-19 }\end{array}$ & $\begin{array}{c}\text { Resistance to } \\
\text { change } \\
\text { Changing } \\
\text { operation methods } \\
\text { Purchasing and } \\
\text { consumption } \\
\text { routines } \\
\text { Unwillingness for } \\
\text { upscaling } \\
\text { Ideological } \\
\text { motivations } \\
\text { Cultural barriers to } \\
\text { cooperation } \\
\text { Eating preferences }\end{array}$ & $\begin{array}{c}\text { Incentives } \\
\text { Proposals and } \\
\text { grants } \\
\text { Political support } \\
\text { Policy reforms } \\
\text { Tax policiesPublic } \\
\text { procurement } \\
\text { policies } \\
\text { European projects } \\
\text { Reduction the } \\
\text { bureaucracy } \\
\text { Lack of quality } \\
\text { control } \\
\text { Disabling } \\
\text { regulatory } \\
\text { frameworks } \\
\text { Hygiene rules }\end{array}$ \\
\hline
\end{tabular}

\subsubsection{Evaluation of $\mathrm{i} / \mathrm{c}$ Statements According to 3 Dimensions}

We identified $286 \mathrm{i} / \mathrm{c}$ statements in selected studies, each of which pointed out an issue or a challenge in SFSCs. We evaluated each i/c statement according to its relation to different SFSC processes, its nature, and the level (e.g., strategic, tactical, operational) of the potential solutions that can address it. The potential solutions were not necessarily mentioned in the reviewed studies.

Through such a methodology that combines several perspectives for evaluating the issues and challenges of SFSCs, we aimed to draw comprehensive and multidimensional conclusions about the limitations and difficulties of SFSCs.

Below, an example statement taken from the study of Borcic [14], as well as the Tables 5 and 6 are used to explain our approach when evaluating the $\mathrm{i} / \mathrm{c}$ statements:

"Another problem related to boxes is that demand is usually much lower in the most productive times of the year. For example, in summer, when the yield is very high and producers can offer the richest boxes, many consumers are on vacation. One of the methods to save their produce from going to waste is to process it, for example by pickling, juicing, drying, making jams, etc." [14] (22p.). 
Table 5. Evaluation of the example statement according to first two dimensions.

\begin{tabular}{|c|c|c|c|}
\hline \multirow{2}{*}{ Relevant Part of the Statement } & \multicolumn{2}{|c|}{ Inference Made } & \multirow{2}{*}{ Details } \\
\hline & SFSC Process & Issue/Challenge Nature & \\
\hline $\begin{array}{c}\text { "... demand is usually much lower } \\
\text { in the most productive times of the } \\
\text { year." } \\
\text { "... in summer, when the yield is } \\
\text { very high ..." }\end{array}$ & $\begin{array}{l}\text { Agricultural } \\
\text { production }\end{array}$ & Upscaling and Marketing & $\begin{array}{l}\text { Variability of the demand } \\
\text { throughout the year relates to } \\
\text { Marketing nature. Lower demand } \\
\text { relates to the Sales process. } \\
\text { Higher productivity in summer } \\
\text { takes place among natural } \\
\text { properties of agricultural } \\
\text { production. }\end{array}$ \\
\hline $\begin{array}{l}\text { "... save their produce from going to } \\
\text { waste is to process it ..." }\end{array}$ & $\begin{array}{c}\text { Waste management, } \\
\text { Planning of food processing, } \\
\text { Food processing }\end{array}$ & $\begin{array}{l}\text { Economic } \\
\text { Social }\end{array}$ & $\begin{array}{l}\text { Food waste is considered an } \\
\text { economic and a social issue. }\end{array}$ \\
\hline
\end{tabular}

Table 6. Evaluation of the example statement according to the third dimension.

\begin{tabular}{|c|c|}
\hline Inference Made & \multirow{2}{*}{ Details } \\
\hline Issue/Challenge Level & \\
\hline Strategic & $\begin{array}{l}\text { We classify this statement as "strategic" since the i/c can be addressed by investing in processing } \\
\text { and/or storage infrastructure, making food processing a part of the business strategy. }\end{array}$ \\
\hline Tactical & $\begin{array}{l}\text { We classify this statement as "tactical" as well, since the i/c can be addressed by using local } \\
\text { infrastructure for processing and/or storage. The excess products can also be processed with the } \\
\text { existing resources, without investing in infrastructure. In this case, food processing is performed only } \\
\text { when necessary and potentially for a smaller quantity of products. }\end{array}$ \\
\hline
\end{tabular}

While interpreting the results we obtained, we formed and made use of a matrix that summarized the review results according to the SFSC processes that we defined (see Section 4). This matrix enabled us make observations related to our research questions.

\section{SFSC Characteristics and Issues}

To better understand the limitations of SFSCs and the need for overcoming them, we should first have a clear idea about the emergence and characteristics of SFSCs, as well as the obstacles to achieving their expected benefits. For this purpose, this section provides such background information, followed by a SWOT analysis and a thematic classification that complements the provided information.

\subsection{Emergence of SFSCS}

Even though industrialization in food systems via long food supply chains has obtained great success in reducing production and distribution costs and in making food available for more people, it has also attracted criticism due to its negative impact on the environment and society $[19,28]$ as well as because of the food safety problems it causes [19]. Consequently, in recent years academics have extensively analyzed the drawbacks of industrialized food systems [18]. The main drawbacks concern environmental damage caused by intensive production and distribution $[18,29,30]$, unfair distribution of margins among supply chain stakeholders [31,32], food safety issues that raise health concerns [18,29,33], and adverse social impacts on society [34]. Over recent decades these drawbacks have led to the emergence of alternative food distribution channels and SFSCs [29,35-38].

\subsection{Characteristics of SFSCs}

Marsden et al. [26] (pp. 424-425) describe SFSCs through their role in "shifting the production of food commodities out of their 'industrial mode' and potentially 'short-circuiting' the long, complex and rationally organized industrial chains within which a decreasing proportion of total added value in food production is captured by primary producers". They emphasize the recently increasing interest in "more local" and "more natural" food products as a trigger for the development of such supply chains, which typically brings back the social interaction between food producers and consumers ("resocializing food"), 
as well as providing food products with an identity through their spatial aspects ("respatializing food"). The authors claim that "locality" of food is a major characteristic of SFSCs but point out that these supply chains can also be "spatially extended" [26]. Kneafsey et al. [2] argue that many researchers who have studied SFSCs accept the description of SFSCs by Marsden et al. [26] and note that some other newer definitions condition the minimum number of (ideally zero) intermediaries. Among the newer definitions in the literature, the below is a comprehensive one that incorporates the main characteristics of SFSCs, offered by Michel-Villarreal et al. [39] based on the SC definition made by Christopher [40]:

"Short Food Supply Chains (SFSCs) are networks of connected and interdependent actors mutually and cooperatively working together to control, manage and improve the flows of information-embedded products, services, resources, and/or information, from farm to fork, seeking a reduction of intermediaries and physical distance between producers and consumers." [39] (3p.).

On the other hand, the European Network for Rural Development [41] emphasizes the enormous variety of SFSCs in EU member countries and concludes that we can interpret them in a flexible manner according to the context and the area in which they function. Accordingly, we use the term SFSCs in this study to include both direct and indirect distribution channels (with one intermediary as suggested by the French Ministry of Agriculture) as well as both spatially proximate and spatially extended settings. It is crucial to emphasize that the core characteristics of SFSCs need to remain valid even in indirect and/or extended scenarios. Accordingly, an initiative should provide their consumers with clear information about products and production processes, establish personal links among all SC stakeholders through fewer intermediaries, offer high quality (e.g., organic, ecologically produced, fresh ... ) food products with spatial identity, and strive to contribute to sustainable production, distribution, and consumption practices to qualify as an SFSC.

\subsection{Thematic Classification of SFSC Studies}

A further analysis that can help describe the characteristics and issues of SFSCs is a thematic classification of the studies in the SFSCs literature. Table 7 below presents in detail the results of the thematic classification we conducted for developing a deeper insight into the literature with regard to the studied topics, while Figure 4 provides a more compact presentation of the same results.

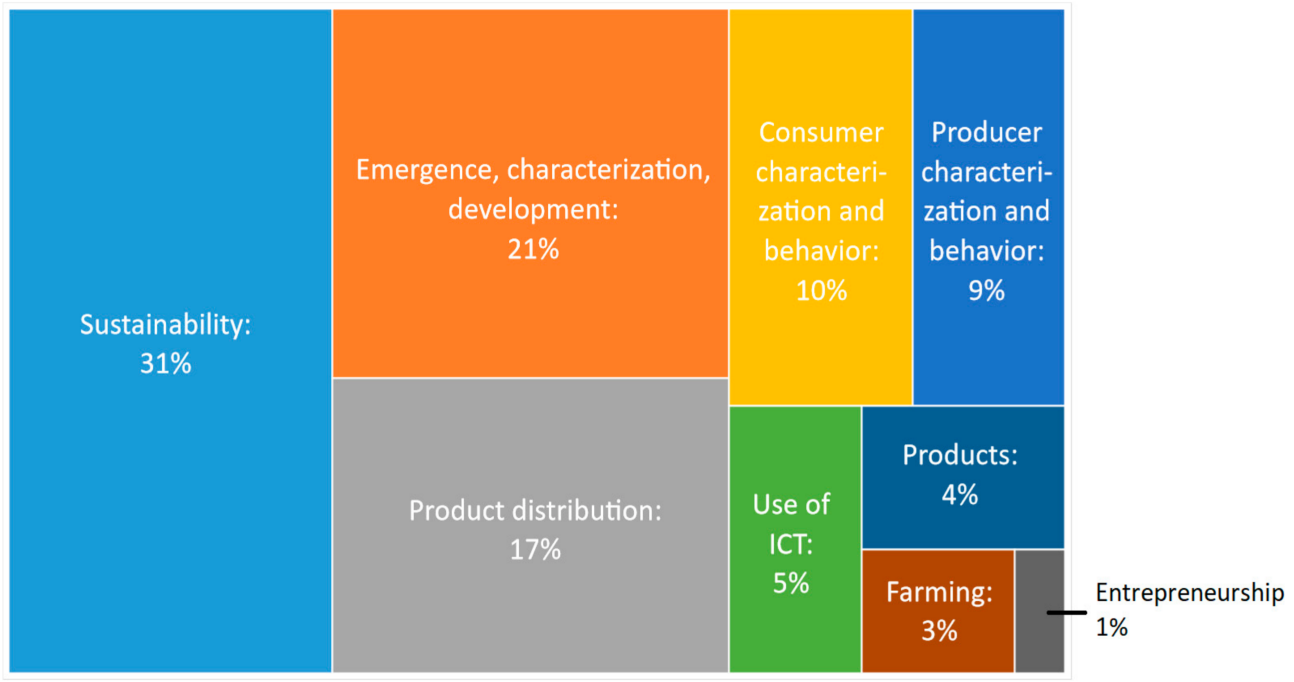

Figure 4. Thematic classification results with the themes grouped. 
Table 7. Thematic classification results in detail.

\begin{tabular}{|c|c|c|}
\hline Group of Themes & Theme & $\begin{array}{l}\text { Number of Times the Theme } \\
\text { Was the Focus of a Study }\end{array}$ \\
\hline & Farming & 9 \\
\hline \multirow{5}{*}{$\begin{array}{c}\text { Emergence, } \\
\text { characterization, } \\
\text { development }\end{array}$} & Emergence of SFSCs & 19 \\
\hline & Market access in SFSCs & 11 \\
\hline & Development of SFSCs & 29 \\
\hline & Characteristics of SFSCs & 8 \\
\hline & SC stakeholders & 3 \\
\hline \multirow{10}{*}{ Product distribution } & Distribution practices & 2 \\
\hline & Distribution infrastructure & 5 \\
\hline & Issues in distribution & 5 \\
\hline & SC disruptions \& resilience & 11 \\
\hline & SC strategies & 28 \\
\hline & Innovations in distribution & 5 \\
\hline & Entrepreneurship, business & \\
\hline & model, & 3 \\
\hline & organizational innovation & \\
\hline & Use of ICT & 17 \\
\hline \multirow{4}{*}{ Sustainability } & Economic sustainability & 38 \\
\hline & Environmental sustainability & 33 \\
\hline & Social sustainability & 30 \\
\hline & Food self-sufficiency & 2 \\
\hline \multirow{3}{*}{$\begin{array}{l}\text { Consumer } \\
\text { characterization and behavior }\end{array}$} & $\begin{array}{c}\text { Purchasing decisions of } \\
\text { consumers }\end{array}$ & 26 \\
\hline & Characteristics of consumers & 3 \\
\hline & Perceptions of consumers & 6 \\
\hline \multirow{6}{*}{$\begin{array}{c}\text { Producer } \\
\text { characterization and behavior }\end{array}$} & $\begin{array}{c}\text { Participation of producers in } \\
\text { SFSCs }\end{array}$ & 19 \\
\hline & Perceptions of producers & 4 \\
\hline & Competences of producers & 3 \\
\hline & Challenges of producers & 3 \\
\hline & Products & 14 \\
\hline & Total & 336 \\
\hline
\end{tabular}

According to these results obtained through 172 studies published between 2000 and 2020 , we can conclude that the evaluated studies frequently concerned the characterization of SFSCs, the producers, or the consumers who participate in them. Based on the findings of the classification, we can also conclude that the sustainability properties of SFSCs are frequently handled in the scientific literature. We can also argue based on the figures that strategic, operational, and organizational aspects of SFSCs such as product distribution, use of information and communication technologies (ICT), and their business models have not had much attention in comparison.

\subsection{Obstacles to Achieving the Expected Benefits of SFSCs}

To facilitate and optimize the movement of food items from production to consumption, conventional food systems function through long food supply chains that involve numerous intermediaries, each of which often specializes in performing one specific activity in the most efficient way possible. SFSCs, on the other hand, are established on the principle of eliminating these intermediaries by putting the producers in the center of commercialization, enhancing their autonomy, and increasing their responsibility along the supply chain.

SFSC stakeholders and researchers often agree on the social benefits brought by SFSCs but not always on the environmental and economic ones [20], which points out the need for further studying and improving the environmental and economic performance of SFSCs. However, ADEME (French public agency for ecological transition) [42] argues that the high variety of SFSC initiatives makes it difficult to study the environmental performance of SFSCs and to confirm that they systematically have a lower negative impact on the 
environment. Similarly, studying their economic viability (costs, profitability, and capacity to expand if necessary) also requires a consideration of specific cases.

Producers who opt for distributing their products through SFSCs are typically smalland medium-scale farmers with limited production and logistics capacities due to insufficient availability of resources such as workforce, infrastructure, skills, and capital. Coupled with their increased responsibility, their smaller scale brings about various issues and challenges that complicate establishing a new SFSC initiative or improving the performance of an existing one. Clearly, the type and significance of these issues and challenges depend on the features of the producer, the farm, the relationship with consumers, as well as the specific initiative of SFSC [43] since these can greatly change from one example to another. For this reason, Borcic [14] argues that farmers engaged in SFSCs must tackle problems that are quite different from those of conventional farmers and that they need to be creative and innovative concerning problem-solving.

Despite the huge variety of SFSCs that requires adapted solutions and strategies, stakeholders of SFSCs often face similar issues and challenges. For example, RucabadoPalomar and Cuellar-Padilla [6] generalize the issues and challenges of SFSCs under the four groups below:

- Need for logistical infrastructure;

- Importance of social links;

- Need for diversifying the distribution channels;

- Product-related constraints.

All in all, distinctive characteristics of SFSCs that attract more and more consumers and producers do not suffice to ensure overall performance and scalability of such SCs. The market conditions in which they operate, and the lack of experience and resources of the participants lead to limitations to achieving their sustainability benefits, which are not limited to economic and environmental dimensions but also include a social aspect (e.g., enabling the access of more people to SFSCs by scaling up). To synthesize all the information about both the strong and weak sides of SFSCs analyzed in the literature, we propose a SWOT analysis as shown in Table 8. Our discussions with 10 SFSC practitioners who are representatives from community supported agriculture initiatives and from logistics service providers for SFSCs as well as individual producers involved in diverse initiatives confirmed the relevance and importance of the elements that are included in the analysis.

Table 8. SWOT analysis for SFSCs.

\begin{tabular}{cc}
\hline Strengths & Weaknesses \\
\hline Local, fresh, and healthy food [31,44-46] & \\
Organic production [14,16,47-49] & Inefficient and costly distribution [3,55-60] \\
Decreased food miles [41] & Limited product availability (e.g., quantity, variety) [17,61,62] \\
High traceability of products during distribution [50] & Lack of processing and/or distribution infrastructure [18,30,63] \\
Increased profits [47] & Limited marketing skills of producers [41] \\
Urban proximity [16,51,52] & Reaching only a small range of consumers [30] \\
Greater autonomy for producers [14,53,54] & Unfamiliarity of consumers with SFSCs [3]
\end{tabular}

\section{Opportunities}

Collaboration with other producers and/or consumers [1,41] Financial support by governments and/or EU [3,32] Public catering (e.g., school/hospital canteens) [64,65]

Development parallel to other sectors (e.g., agritourism) [66] Use of existing infrastructure (e.g., sales points) [41] Food hubs/platforms [65]

Increased consumer knowledge and trust in producers [67-70] Development and attractivity of e-grocery $[3,71]$
Global and efficient food supply chains with easy-to-reach sales channels (e.g., supermarkets) [60] High prices for buying land [41]

Highly time-oriented buying habits of consumers (e.g., demand for immediate access to products) [72] Excessive standards and/or legal requirements [50]

Finding the balance between scaling up and preserving SFSC characteristics [30] 
The "weaknesses" and "threats" presented in the SWOT analysis acknowledge the existence of various issues and challenges that hinder better performance and scalability, supporting our motivations to conduct this study.

\section{Results and Discussion}

Despite the growing demand for SFSC products and the potential of SFSCs for improving the sustainability and resilience of food systems, performance improvement and upscaling of such SCs remain difficult to achieve due to numerous issues and challenges. The systematic literature review that we conducted was aimed at providing the reader with a better understanding of the $\mathrm{i} / \mathrm{c}$ in SFSC s through a holistic evaluation of the scientific literature.

In this section, we share the results of the systematic review and interpret the results to look for answers to each research question of the study. Table 9 below summarizes the results of the review in terms of $i$ / c statements identified per SFSC process. On each line, the ratio of statements that relate to each $\mathrm{i} / \mathrm{c}$ level and each $\mathrm{i} / \mathrm{c}$ nature are represented as percentages. The cells are highlighted in different shades, differentiating between $0 \%$ to $25 \%, 26 \%$ to $50 \%, 51 \%$ to $75 \%$, and $76 \%$ to $100 \%$. For example, concerning the SFSC process of "product distribution (in general sense)", we identified 178 statements in 41 studies. Of these statements $99 \%$ are classified as "strategic" and $74 \%$ of them as "upscaling and marketing".

Table 9. Findings of the systematic literature review, per SFSC process.

\begin{tabular}{|c|c|c|c|c|c|c|c|c|c|c|c|c|c|c|c|c|c|}
\hline & & & & & & $\% 0$ & Times & That $\mathrm{t}$ & he Sta & teme & ents A & re Cla & ssifie & & & & \\
\hline & & & & Level & & & & & & & Natur & & & & & & \\
\hline SFSC Process & 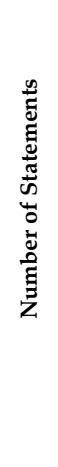 & 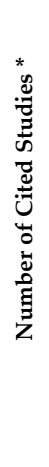 & 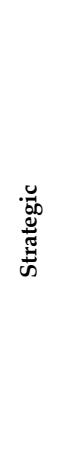 & 莺 & 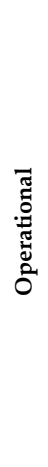 & 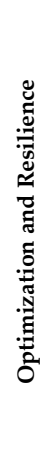 & 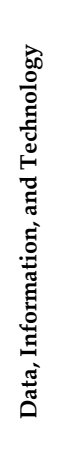 & 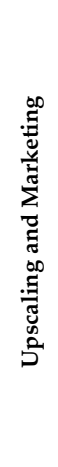 & 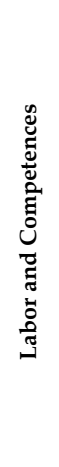 & 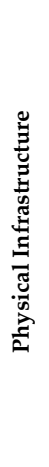 & 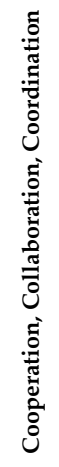 & 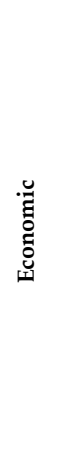 & 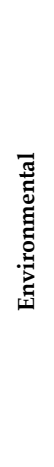 & 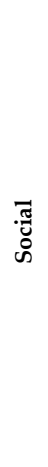 & 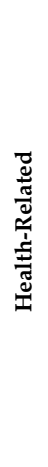 & 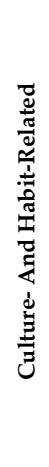 & 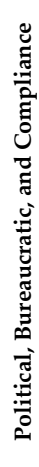 \\
\hline $\begin{array}{l}\text { Planning of agricultural } \\
\text { production }\end{array}$ & 10 & 5 & 100 & 70 & 40 & 70 & 50 & 70 & 80 & 30 & 40 & 50 & 40 & 50 & 30 & 20 & 20 \\
\hline Planning of food processing & 6 & 4 & 100 & 67 & 17 & 50 & 50 & 84 & 67 & 17 & 34 & 50 & 34 & 67 & 34 & 0 & 34 \\
\hline $\begin{array}{c}\text { Planning of logistics } \\
\text { activi-ties }\end{array}$ & 24 & 16 & 100 & 92 & 79 & 96 & 50 & 67 & 50 & 30 & 46 & 55 & 50 & 50 & 9 & 25 & 17 \\
\hline Sourcing agricultural input & 1 & 1 & 100 & 100 & 0 & 0 & 0 & 0 & 0 & 0 & 0 & 100 & 0 & 0 & 0 & 0 & 0 \\
\hline $\begin{array}{c}\text { Sourcing packaging } \\
\text { mate-rial }\end{array}$ & 1 & 1 & 100 & 100 & 0 & 0 & 0 & 0 & 0 & 0 & 0 & 100 & 0 & 0 & 0 & 0 & 0 \\
\hline Agricultural production & 70 & 31 & 99 & 64 & 36 & 28 & 36 & 78 & 40 & 25 & 28 & 46 & 35 & 26 & 20 & 26 & 23 \\
\hline Food processing & 58 & 22 & 98 & 50 & 24 & 38 & 38 & 83 & 49 & 35 & 23 & 56 & 16 & 26 & 23 & 18 & 26 \\
\hline Order management & 2 & 2 & 100 & 100 & 50 & 50 & 100 & 100 & 100 & 50 & 50 & 50 & 50 & 50 & 50 & 50 & 0 \\
\hline Packaging & 5 & 4 & 100 & 40 & 40 & 80 & 20 & 80 & 40 & 40 & 40 & 60 & 20 & 40 & 20 & 0 & 20 \\
\hline Transportation & 28 & 19 & 100 & 82 & 82 & 86 & 29 & 68 & 40 & 43 & 33 & 58 & 58 & 33 & 15 & 22 & 25 \\
\hline Sales & 167 & 39 & 100 & 50 & 33 & 32 & 44 & 90 & 38 & 23 & 31 & 51 & 16 & 45 & 18 & 25 & 22 \\
\hline Consumption & 4 & 3 & 100 & 75 & 25 & 25 & 50 & 75 & 50 & 0 & 50 & 50 & 25 & 50 & 25 & 75 & 25 \\
\hline Waste management & 5 & 4 & 100 & 80 & 40 & 40 & 20 & 80 & 20 & 20 & 20 & 60 & 60 & 60 & 20 & 20 & 20 \\
\hline Storage & 6 & 5 & 100 & 100 & 50 & 67 & 50 & 100 & 67 & 67 & 34 & 67 & 67 & 50 & 34 & 34 & 0 \\
\hline $\begin{array}{l}\text { Product distribution } \\
\text { (in general sense) }\end{array}$ & 178 & 41 & 99 & 46 & 28 & 34 & 38 & 74 & 45 & 24 & 45 & 43 & 17 & 48 & 15 & 22 & 24 \\
\hline Reverse logistics & 1 & 1 & 100 & 100 & 0 & 0 & 0 & 0 & 0 & 0 & 0 & 0 & 100 & 0 & 0 & 0 & 0 \\
\hline
\end{tabular}

* Refer to Table A1 in Appendix A for the list of cited studies per SFSC process. 


\subsection{RQ 1: At Which Parts of the SFSCs Do the Issues and Challenges Occur?}

4.1.1. Observation 1: Most Studies Focus on i/c Encountered in Product Distribution and Production Processes in SFSCs

The findings confirm the motivation behind this study that the existing literature tends to focus on some parts of the SFSCs while neglecting to take into consideration some others. Referring to Section 1, the results of our review support the argument that most studies focus on product distribution and production i/c in SFSCs [24]. As seen in Table 9 above, most of the selected studies mention at some point an $\mathrm{i} / \mathrm{c}$ about the product distribution (in general sense) (93\% of cited papers) or the sales process within product distribution (89\% of cited papers). Following the product distribution and sales, $70 \%$ and $50 \%$ of the cited studies, respectively, specify agricultural production and food processing issues and challenges. About the tendency to focus on the product distribution process, we also observe that the transportation and planning of logistics activities processes also take place among the frequently mentioned SFSC i/c, $43 \%$ and $36 \%$, respectively.

4.1.2. Observation 2: Authors Tend to Overly Generalize Their Statements about Product Distribution i/c in SFSC: Product Distribution (in General Sense)

The large number of statements and cited studies that mention the product distribution process in SFSCs in a general sense confirm the importance of this process. Nonetheless, they also show that the literature tends to overly generalize the occurrence of SFSC $i / c$ and that it does not mention the specific process within the product distribution (namely order management, packaging, consumption, waste management, and storage).

\subsubsection{Observation 3: Planning, Sourcing, and Reverse Logistics Are Under-Studied} SFSC Processes

In addition to the overlooked processes within product distribution, the results also point out three different groups of SFSC processes that are under-studied. First, consideration of the SC process planning is limited to the logistics activities in the SFSCs research. Planning of food processing and planning of agricultural production are neglected subjects, even though they are critical in terms of aligning supply and demand. Second, the SC process of sourcing is completely an under-studied subject in the SFSCs literature. Finally, the existing studies do not pay attention to the reverse logistics process.

\subsection{RQ 2: How Can We Characterize the Issues and Challenges in SFSCs?}

4.2.1. Observation 1: Strategic and Tactical i/c with Upscaling-Marketing and Economic Nature Are Dominant along the SFSC

Identified i/c statements in SFSCs point out a large dominance of strategic and tactical levels. This is due to the small scale and limited resources of such initiatives, leading to the conclusion that most problems they encounter can be addressed by long-term plans such as investing in infrastructure, gaining knowledge and experience, and restructuring the SCs. As per the i/c natures, the results show that upscaling-marketing and economic i/c are crucial along the SFSC. The dominance of strategic and tactical levels as well as of upscalingmarketing and economic natures supports the claimed difficulty in upscaling the SFSCs (refer to the Introduction) and leads to the conclusion that this difficulty mainly relates to a lack of financial and human resources, a lack of infrastructure, as well as to a need for better marketing organization (e.g., facilitated flow of materials) and for optimization (e.g., cost minimization) along the SC.

4.2.2. Observation 2: Planning of Logistics Activities and Transportation Can Be Improved over a Shorter Term Than Other Processes

According to the overall results, $99 \%$ of all $\mathrm{i} / \mathrm{c}$ statements relate to the strategic level and $54 \%$ to the tactical level, while only $32 \%$ relate to the operational level. However, as seen in Figure 5, the distribution among the three levels differs according to the SFSC processes. Based on the number of statements identified, only the SFSC processes that have a higher number of statements are considered here. 


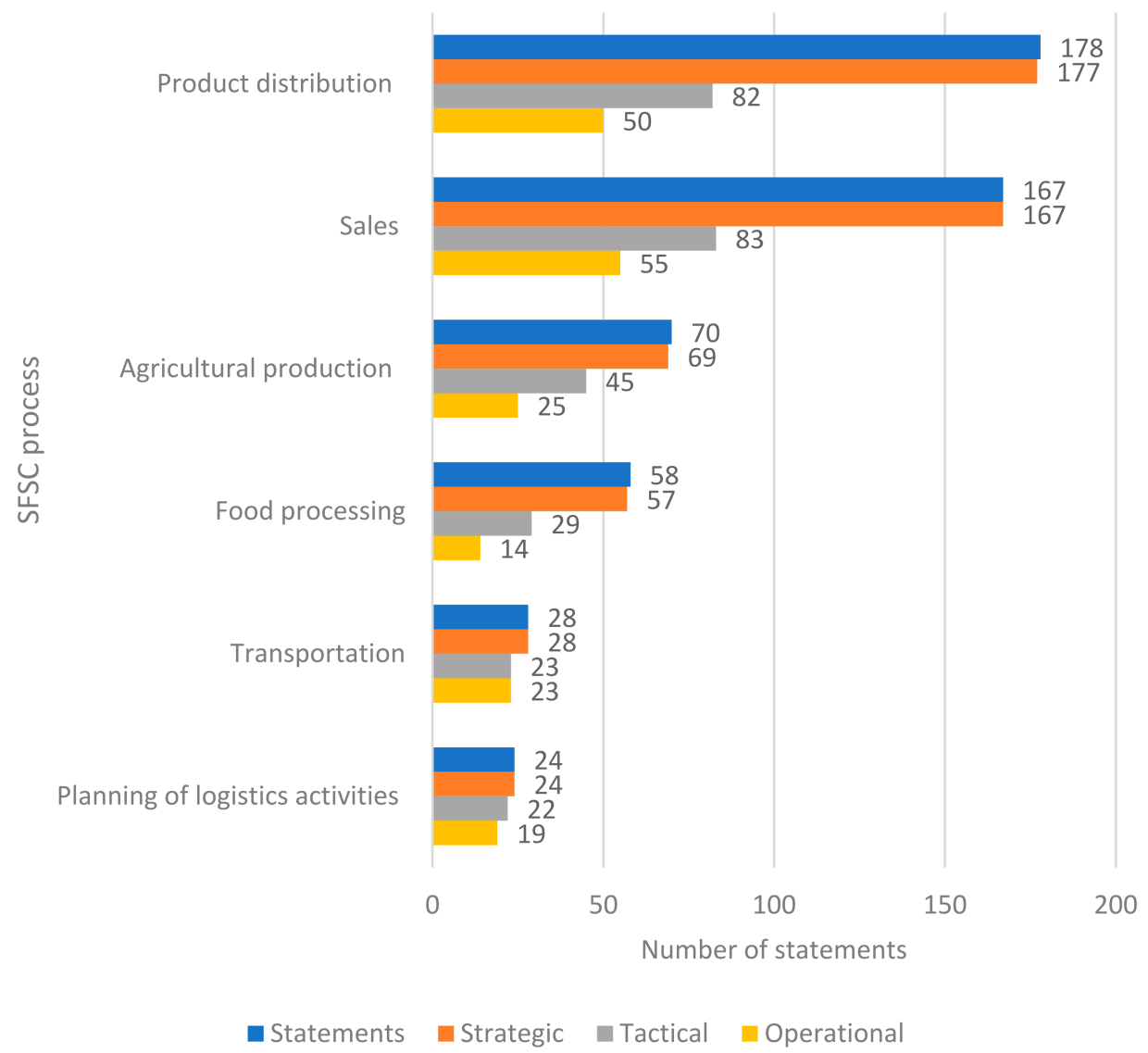

Figure 5. Number of i/c statements and their levels per SFSC process.

As in Figure 5 above, we observed that agricultural production, food processing, sales, and product distribution (in general sense) all have a heterogeneous distribution among the strategic, tactical, and operational levels. For these processes, nearly all the i/c mentioned require the implementation of strategic-level plans or solutions. Considering the statements that led to these findings, this is due to the need for improved infrastructure in such processes.

On the other hand, the processes planning of logistics activities and transportation have rather homogeneous distributions among the three levels. In other words, issues and challenges encountered in these processes can also be addressed by adopting solutions implemented in the short-term without needing to make heavy investments. In a way to support this claim, we also observed that the dominant $i / c$ nature for these processes is optimization-resilience, which relates to operational-level improvement approaches such as vehicle routing.

4.2.3. Observation 3: Health-Related, Culture- and Habit-Related, and Political-Bureaucratic Aspects of SFSC i/c Are Under-Mentioned

In the scope of this study, we defined health-related, culture- and habit-related, and political-bureaucratic natures based on our knowledge of SFSCs, by assuming that they take place among important aspects of such SCs. However, interestingly, the results show that they do not take place among the frequently mentioned $\mathrm{i} / \mathrm{c}$ natures. This can be because they are frequently handled in the context of SFSC characterization but not in terms of the issues and challenges encountered in SFSCs. 


\section{Conclusions}

\subsection{Main Findings and Contributions of the Study}

SFSCs have been gaining popularity among producers and consumers in recent decades. However, their stakeholders have faced various issues and challenges that result in poor performance and difficulties in upscaling. To meet increasing customer demand and realize their claims of more sustainable and resilient food systems, SFSCs need to overcome their issues and challenges and become better performing and more scalable.

The goal of this study was to use SCM knowledge to offer a holistic, end-to-end, vision for SFSCs by examining their issues and challenges. To do so, we conducted a systematic review of the recent literature through full-text content analysis. We used SFSC processes and issue/challenge natures that we defined based on the SCOR model and our knowledge about SFSCs, as well as strategic-tactical-operational issue/challenge levels while conducting the content analysis. We used the results we obtained to find answers to the research questions of this study.

The findings helped improve our understanding of the issues and challenges in SFSCs holistically, by questioning every SFSC process, issue/challenge nature, and issue/challenge level and pointing out several gaps in the existing literature. First, most studies only focus on $\mathrm{i} / \mathrm{c}$ in production and distribution processes in SFSCs. While mentioning product distribution issues and challenges, they often generalize them and do not particularly discuss order management, packaging, or storage processes. In line with the general tendency to handle product distribution and production issues and challenges, SFSC processes such as planning, sourcing, and reverse logistics are under-studied. Furthermore, strategic and tactical levels, as well as upscaling-marketing and economic natures are dominant along the SFSC. The only SFSC processes that appear to have operational issues and challenges are the planning of logistics activities and transportation. Among the SFSC issue/challenge natures we defined, health-related, culture- and habit-related, and political-bureaucratic issues and challenges are under-mentioned.

This study contributes to the literature by offering a holistic overview of issues and challenges encountered in SFSCs. The identification of SFSC processes that we have conducted in this study to ensure an end-to-end consideration of SFSCs is, to the best our knowledge, a first in the literature. Moreover, the definition of natures and the use of levels for characterizing the issues and challenges of SFSCs is also a novelty offered in this study. Developing a deeper insight into the issues and challenges of SFSCs and embracing a holistic perspective while doing so are particularly critical in this area of research since SFSC initiatives are newly emerging, and there is a crucial need for improving their performance. Such a contribution is particularly important because the SFSC literature is mostly built around describing the characteristics of these initiatives rather than focusing on their problems and searching for solutions to these problems. Therefore, a review of their issues and challenges points out the need for studying SFSCs not only with a descriptive, but also with a diagnostic and prescriptive approach.

\subsection{Limitations}

This study also has limitations concerning its methodology as well as limitations that derive from its materials.

First, the systematic review was based on full-text reading and content analysis, where we identified statements that implied issues or challenges, made their connections to SFSC processes, classified them into different issue/challenge natures, and decided the levels of potential solutions according to our understanding. To reduce the impact of subjectivity, we followed keyword patterns in our decisions.

Another limitation concerns the materials we used and comes from the general and/or ambiguous expressions used in the cited studies while mentioning SFSCs' issues and challenges. For example, agricultural production and food processing processes are often generalized as "production", requiring attributing the statement to both processes during evaluation. This limitation decreased our ability to detect agricultural production 
and food processing issues and challenges separately and blurred the line between these two processes.

A further limitation that derived from the materials was the use of the term SFSC in the literature. Even though there is an abundance of definitions for SFSCs, there is a consensus that they are not necessarily local, organic, or direct supply chains (see Figure 1 in Section 1). Nonetheless, researchers frequently reduce the scope of SFSCs to local food supply chains in their studies. More accurate use of the terminology can facilitate the researchers' access to the studies with the right focus and enable them to make historically more extended literature reviews.

\subsection{Perspectives for Future Research}

To conclude the study, we offer some perspectives for future research about SFSCs based on the findings of the systematic literature review. In our opinion, it is important to include the under-studied SFSC processes such as planning, sourcing, reverse logistics, order management, packaging, consumption, waste management, and storage in future theoretical efforts and case studies. The impact of these processes on the performance of SFSCs needs to be studied to propose appropriate solutions and strategies for an overall improvement of SFSCs' performance. Similarly, under-mentioned i/c natures such as health-related and culture- and habit-related aspects can be considered more in future endeavors. Another further research direction concerns identifying the relations among the SFSC processes, for example by making use of the issue/challenge natures. This way, the literature can evolve toward a holistic and integrated SFSC vision and offer more realistic and effective modeling approaches and improvement strategies.

Finally, reviewing the literature in terms of the issues and challenges of SFSCs in the years to come can enable researchers to observe and verify the changes that occur in the distribution of the issues and challenges handled in the literature. For example, the attention paid to sourcing issues and challenges can increase due to concerns about supply chain disruptions as experienced during the COVID-19 pandemic.

Author Contributions: Conceptualization, B.B., A.C., A.S. and Y.O.; methodology, B.B., A.C., A.S. and Y.O.; validation, B.B., A.C., A.S. and Y.O.; investigation, B.B.; resources, B.B.; writing-original draft preparation, B.B.; writing-review and editing, B.B., A.C., A.S. and Y.O.; visualization, B.B., A.C., A.S. and Y.O.; supervision, A.C., A.S. and Y.O.; project administration, B.B., A.C., A.S. and Y.O. All authors have read and agreed to the published version of the manuscript.

Funding: This research received no external funding.

Institutional Review Board Statement: Not applicable.

Informed Consent Statement: Not applicable.

Data Availability Statement: The data presented in this study are available on request from the corresponding author.

Acknowledgments: The authors acknowledge the Erasmus+ project SUNSpACe, that is referred by "598748-EPP-1-2018-1-FR-EPPKA2-CBHE-JP" funded with support from the European Commission. This publication reflects the views only of the authors, and the Commission cannot be held responsible or any use which may be made of the information contained therein.

Conflicts of Interest: The authors declare no conflict of interest. 


\section{Appendix A}

Table A1. Studies where we found i/c statements, per SFSC process.

\begin{tabular}{cc}
\hline SFSC Process & Studies That Mention Relevant Issues or Challenges \\
\hline Planning of agricultural production & {$[14,16,62,73,74]$} \\
\hline Planning of food processing & {$[14,16,62,74]$} \\
\hline Planning of logistics activities & {$[3,9,10,14-17,20,23,25,62,74-78]$} \\
\hline Sourcing agricultural input & {$[24]$} \\
\hline Sourcing packaging material & {$[3,6,8,10,11,13-17,20,21,23-25,61,62,64,73,74,77-87]$} \\
\hline Agricultural production & {$[3,6,8,10,11,13,14,16,17,20,21,23-25,39,62,64,74,77,78,80,82]$} \\
\hline Food processing & {$[14,39]$} \\
\hline Order management & {$[6,17,24,74]$} \\
\hline Packaging & {$[3,6,9-11,14,16,17,20,23-25,39,64,76,78,81-83]$} \\
\hline Transportation & {$[14,47,83]$} \\
\hline Sales & {$[14,17,39,61]$} \\
\hline Consumption & {$[3,14,17,39,87]$} \\
\hline Waste management & {$[12,14-17,20,21,23-25,39,47,61,62,64,74,75,77-92]$} \\
\hline Storage &
\end{tabular}

\section{References}

1. Jarzebowski, S.; Pietrzyck, K. The concept of short supply chains in the food economy. In Proceedings of the International Scientific Conference "The Common Agricultural Policy of the European Union-The present and the future", Stare Jablonski, Poland, 5-7 December 2017. [CrossRef]

2. Kneafsey, M.; Venn, L.; Schmutz, U.; Balazs, B.; Trenchard, L.; Eyden-Wood, T.; Bos, E.; Sutton, G.; Blackett, M. Short food supply chains and local food systems in the EU. A state of play of their socio-economic characteristics. In Report Number: 25911 EN Project: Agroecology and Organic Horticulture Research; Santini, F., Gomez y Paloma, S., Eds.; Publications Office: Luxembourg, 2013. [CrossRef]

3. Elghannam, A.; Mesias, F.J.; Escribano, M.; Fouad, L.; Horrillo, A.; Escribano, A.J. Consumers' perspectives on alternative short food supply chains based on social media: A focus group study in Spain. Foods 2020, 9, 22. [CrossRef] [PubMed]

4. Plakias, Z.T.; Demko, I.; Katchova, A.L. Direct marketing channel choices among US farmers: Evidence from the local food marketing practices survey. Renew. Agric. Food Syst. 2020, 35, 475-489. [CrossRef]

5. Dragicevic, A.Z. Emergence and dynamics of short food supply chains. Networks Spat. Econ. 2020, 21, 31-55. [CrossRef]

6. Rucabado-Palomar, T.; Cuellar-Padilla, M. Short food supply chains for local food: A difficult path. Renew. Agric. Food Syst. 2020, 35, 182-191. [CrossRef]

7. Agriculture Strategies. Available online: https://www.agriculture-strategies.eu/en/2021/03/short-food-supply-chain-anddirect-sale-around-preconceived-ideas / (accessed on 19 January 2022).

8. Kiss, K.; Ruszkai, C.; Szucs, A.; Koncz, G. Examining the role of local products in rural development in the light of consumer preferences-Results of a consumer survey from Hungary. Sustainability 2020, 12, 5473. [CrossRef]

9. Galati, A.; Giacomarra, M.; Concialdi, P.; Crescimanno, M. Exploring the feasibility of introducing electric freight vehicles in the short food supply chain: A multi-stakeholder approach. Case Stud. Transp. Policy 2021, 9, 950-957. [CrossRef]

10. Gonzalez-Azcarate, M.; Macein, J.L.C.; Bardaji, I. Why buying directly from producers is a valuable choice? Expanding the scope of short food supply chains in Spain. Sustain. Prod. Consum. 2021, 26, 911-920. [CrossRef]

11. Horska, E.; Petrilak, M.; Sedik, P.; Nagyova, L. Factors influencing the sale of local products through short supply chains: A case of family dairy farms in Slovakia. Sustainability 2020, 12, 8499. [CrossRef]

12. Charatsari, C.; Kitsios, F.; Lioutas, E.D. Short food supply chains: The link between participation and farmers' competencies. Renew. Agric. Food Syst. 2020, 35, 643-652. [CrossRef]

13. Alvarez, A.; Garcia-Cornejo, B.; Perez-Mendez, J.A.; Roibas, D. Value-creating strategies in dairy farm entrepreneurship: A case study in northern Spain. Animals 2021, 11, 1396. [CrossRef]

14. Borcic, L.S. Short food supply chains in Croatia: Perspectives of organic food producers involved with groups of solidary exchange. Hrvat. Geogr. Glas. 2020, 82, 5-33. [CrossRef]

15. Kurtsal, Y.; Ayalp, E.K.; Viaggi, D. Exploring governance mechanisms, collaborative processes and main challenges in short food supply chains: The case of Turkey. Bio-Based Appl. Econ. 2020, 9, 201-221. [CrossRef] 
16. Ochoa, C.Y.; Ruiz, A.M.; Olmo, R.M.; Figueroa, Á.M.; Rodríguez, A.T. Peri-urban organic agriculture and short food supply chains as drivers for strengthening city/region food systems-two case studies in Andalucia, Spain. Land 2020, 9, 177. [CrossRef]

17. Paciarotti, C.; Torregiani, F. The logistics of the short food supply chain: A literature review. Sustain. Prod. Consum. 2021, 26, 428-442. [CrossRef]

18. Bazzani, C.; Canavari, M. Alternative agri-food networks and short food supply chains: A review of the literature. Econ. Agro-Aliment. 2013, 15, 11-34. [CrossRef]

19. Kumar, V.; Wang, M.; Kumari, A.; Akkaranggoon, S.; Garza-Reyes, J.A.; Neutzling, D.; Tupa, J. Exploring short food supply chains from triple bottom line lens: A comprehensive systematic review. In Proceedings of the International Conference on Industrial Engineering and Operations Management, Bangkok, Thailand, 5-7 March 2019.

20. Chiffoleau, Y.; Dourian, T. Sustainable food supply chains: Is shortening the answer? A literature review for a research and innovation agenda. Sustainability 2020, 12, 9831. [CrossRef]

21. Thome, K.M.; Cappellesso, G.; Ramos, E.L.A.; de Lima Duarte, S.C. Food supply chains and short food supply chains: Coexistence conceptual framework. J. Clean. Prod. 2021, 278, 123207. [CrossRef]

22. Todorovic, V.; Maslaric, M.; Bojic, S.; Jokic, M.; Mircetic, D.; Nikolicic, S. Solutions for more sustainable distribution in the short food supply chains. Sustainability 2018, 10, 3481. [CrossRef]

23. Jarzebowski, S.; Bourlakis, M.; Bezat-Jarzebowska, A. Short food supply chains (SFSC) as local and sustainable systems. Sustainability 2020, 12, 4715. [CrossRef]

24. Bui, T.N.; Nguyen, A.H.; Le, T.T.H.; Nguyen, V.P.; Le, T.T.H.; Tran, T.T.H.; Nguyen, N.M.; Le, T.K.O.; Nguyen, T.K.O.; Nguyen, T.T.T.; et al. Can a short food supply chain create sustainable benefits for small farmers in developing countries? An exploratory study of Vietnam. Sustainability 2021, 13, 2443. [CrossRef]

25. Pato, M.L. Short food supply chains-a growing movement. The case study of the Viseu Dão Lafões Region. Open Agric. 2020, 5, 806-816. [CrossRef]

26. Marsden, T.; Banks, J.; Bristow, G. Food supply chain approaches: Exploring their role in rural development. Sociol. Ruralis 2000, 40, 424-438. [CrossRef]

27. APICS. SCOR-Supply Chain Operations Reference Model. 2017. Available online: https://www.logsuper.com/ueditor/php/ upload/ file/20190530/1559181653829933.pdf (accessed on 19 January 2022).

28. Forssell, S.; Lankoski, L. The sustainability promise of alternative food networks: An examination through "Alternative" characteristics. Agric. Hum. Values 2015, 32, 63-75. [CrossRef]

29. Mundler, P.; Criner, G. Food systems: Food miles. In Encyclopedia of Food and Health; Elsevier Inc.: Amsterdam, The Netherlands, 2016; pp. 77-82. [CrossRef]

30. Aggestam, V.; Fleiss, E.; Posch, A. Scaling-up short food supply chains? A survey study on the drivers behind the intention of food producers. J. Rural Stud. 2017, 51, 64-72. [CrossRef]

31. Aguglia, L.; De Santis, F.; Salvioni, C. Direct selling: A marketing strategy to shorten distances between production and consumption. In Proceedings of the 113th EAAE Seminar "A resilient European Food Industry and Food Chain in a Challenging World", Chania, Greece, 3-6 September 2009.

32. Andrei, J.V.; Ion, R.A.; Chivu, L.; Pop, R.E.; Marin, A. Investigations on farmers' willingness to associate and join in environmental responsible short supply chain in Romania. Appl. Ecol. Environ. Res. 2019, 17, 1617-1639. [CrossRef]

33. Feldmann, C.; Hamm, U. Consumers' perceptions and preferences for local food: A review. Food Qual. Prefer. 2015, 40, 152-164. [CrossRef]

34. Hinrichs, C.C. Embeddedness and local food systems: Notes on two types of direct agricultural market. J. Rural Stud. 2000, 16, 295-303. [CrossRef]

35. Chiffoleau, Y.; Millet-Amrani, S.; Rossi, A.; Rivera-Ferre, M.G.; Merino, P.L. The participatory construction of new economic models in short food supply chains. J. Rural Stud. 2019, 68, 182-190. [CrossRef]

36. Renting, H.; Marsden, T.K.; Banks, J. Understanding alternative food networks: Exploring the role of short food supply chains in rural development. Environ. Plan. A 2003, 35, 393-411. [CrossRef]

37. Maye, D.; Kirwan, J. Alternative Food Networks. 2010. Available online: https://sociopedia.isaportal.org/resources/resource/ alternative-food-networks / download/ (accessed on 17 January 2022).

38. Goodman, D.; Goodman, M.K. Alternative food networks. In International Encyclopedia of Human Geography; Elsevier: Amsterdam, The Netherlands, 2009.

39. Michel-Villarreal, R.; Vilalta-Perdomo, E.L.; Canavari, M.; Hingley, M. Resilience and digitalization in short food supply chains: A case study approach. Sustainability 2021, 13, 5913. [CrossRef]

40. Christopher, M. Logistics and Supply Chain Management, 5th ed.; Pearson Education Limited: Harlow, UK, 2016.

41. European Network for Rural Development. Local Food and Short Supply Chains. 2012. Available online: https://enrd.ec.europa. eu/sites/default/ files/E8F24E08-0A45-F272-33FB-A6309E3AD601.pdf (accessed on 6 January 2022).

42. ADEME. Les Avis de l'ADEME, Alimentation—Les Circuits Courts de Proximité. 2017. Available online: https://www.ademe.fr/ sites/default/files/assets/documents/avis-ademe-circuits-courts.pdf (accessed on 3 January 2022).

43. Belletti, G.; Marescotti, A. Short Food Supply Chains for Promoting Local Food on Local Markets. United Nations Industrial Development Organization. 2020. Available online: https:/ / suster.org/wp-content/uploads/2020/06/SHORT-FOOD-SUPPLYCHAINS.pdf (accessed on 5 January 2022). 
44. Testa, R.; Migliore, G.; Schifani, G.; Tinebra, I.; Farina, V. Chemical-physical, sensory analyses and consumers' quality perception of local vs. imported loquat fruits: A sustainable development perspective. Agronomy 2020, 10, 870. [CrossRef]

45. Brulard, N.; Cung, V.D.; Catusse, N.; Dutrieux, C. An integrated sizing and planning problem in designing diverse vegetable farming systems. Int. J. Prod. Res. 2019, 57, 1018-1036. [CrossRef]

46. Kallas, Z.; Alba, M.F.; Casellas, K.; Berges, M.; Degreef, G.; Gil, J.M. The development of short food supply chain for locally produced honey: Understanding consumers' opinions and willingness to pay in Argentina. Br. Food J. 2019, 123, 1664-1680. [CrossRef]

47. Tundys, B.; Wisniewski, T. Benefit optimization of short food supply chains for organic products: A simulation-based approach. Appl. Sci. 2020, 10, 2783. [CrossRef]

48. Rover, O.J.; da Silva Pugas, A.; De Gennaro, B.C.; Vittori, F.; Roselli, L. Conventionalization of organic agriculture: A multiple case study analysis in Brazil and Italy. Sustainability 2020, 12, 6580. [CrossRef]

49. Iocola, I.; Campanelli, G.; Diacono, M.; Leteo, F.; Montemurro, F.; Persiani, A.; Canali, S. Sustainability assessment of organic vegetable production using a qualitative multi-attribute model. Sustainability 2018, 10, 3820. [CrossRef]

50. Sellitto, M.A.; Vial, L.A.M.; Viegas, C.V. Critical success factors in short food supply chains: Case studies with milk and dairy producers from Italy and Brazil. J. Clean. Prod. 2018, 170, 1361-1368. [CrossRef]

51. Bermond, M.; Guillemin, P.; Marechal, G. Which geography of agricultural transitions in France? An exploratory approach from organic farming and short food supply chains in the 2010 agricultural census. Cah. Agric. 2019, 28, 16. [CrossRef]

52. Karg, H.; Drechsel, P.; Akoto-Danso, E.K.; Glaser, R.; Nyarko, G.; Buerkert, A. Foodsheds and city region food systems in two west African cities. Sustainability 2016, 8, 1175. [CrossRef]

53. Dupre, L.; Lamine, C.; Navarrete, M. Short food supply chains, long working days: Active work and the construction of professional satisfaction in French diversified organic market gardening. Sociol. Ruralis. 2017, 57, 396-414. [CrossRef]

54. Guzman, G.I.; Lopez, D.; Roman, L.; Alonso, A.M. Participatory action research in agroecology: Building local organic food networks in Spain. Agroecol. Sustain. Food Syst. 2013, 37, 127-146. [CrossRef]

55. Ochoa, C.Y.; Mataran, A.; Olmo, R.M.; Lopez, J.; Fuentes-Guerra, R. The potential role of short food supply chains in strengthening periurban agriculture in Spain: The cases of Madrid and Barcelona. Sustainability 2019, 11, 2080. [CrossRef]

56. Aiello, G.; Giovino, I.; Vallone, M.; Catania, P. A multi objective approach to short food supply chain management. Chem. Eng. Trans. 2017, 58, 313-318. [CrossRef]

57. Gruchmann, T.; Bohm, M.; Krumme, K.; Funcke, S.; Hauser, S.; Melkonyan, A. Local and sustainable food businesses: Assessing the role of supply chain coordination. In Innovative Logistics Services and Sustainable Lifestyles: Interdependencies, Transformation Strategies and Decision Making; Springer International Publishing: New York, NY, USA, 2019; pp. 143-163. [CrossRef]

58. EIP-AGRI. EIP-AGRI Focus Group Innovative Short Food Supply Chain Management. 2015. Available online: https://ec.europa eu/eip/agriculture/sites/default/files/eip-agri_fg_innovative_food_supply_chain_management_final_report_2015_en.pdf (accessed on 3 January 2022).

59. Nsamzinshuti, A.; Janjevic, M.; Rigo, N.; Ndiaye, A.B. Short supply chains as a viable alternative for the distribution of food in urban areas? Investigation of the performance of several distribution schemes. In Sustainable Freight Transport; Springer: New York, NY, USA, 2018; Volume 63, pp. 99-119. [CrossRef]

60. Kiss, K.; Ruszkai, C.; Takacs-Gyorgy, K. Examination of short supply chains based on circular economy and sustainability aspects. Resources 2019, 8, 161. [CrossRef]

61. Butu, A.; Bruma, I.S.; Tanasa, L.; Rodino, S.; Vasiliu, C.D.; Dobos, S.; Butu, M. The impact of COVID-19 crisis upon the consumer buying behavior of fresh vegetables directly from local producers. Case study: The quarantined area of Suceava county, Romania. Int. J. Environ. Res. Pub. Health 2020, 17, 5485. [CrossRef]

62. Thilmany, D.; Canales, E.; Low, S.A.; Boys, K. Local food supply chain dynamics and resilience during COVID-19. Appl. Econ. Perspect. Policy 2020, 43, 86-104. [CrossRef]

63. Ross, N.J. How civic is it? Success stories in locally focused agriculture in Maine. Renew. Agric. Food Syst. 2006, 21, 114-123. [CrossRef]

64. Le Velly, R.; Goulet, F.; Vinck, D. Allowing for detachment processes in market innovation. The case of short food supply chains. Consum. Mark. Cult. 2020, 24, 313-328. [CrossRef]

65. Dimitri, C.; Gardner, K. Farmer use of intermediated market channels: A review. Renew. Agric. Food Syst. 2019, 34, 181-197. [CrossRef]

66. Arru, B.; Furesi, R.; Madau, F.A.; Pulina, P. "Value Portfolio", value creation and multifunctionality: The case study of an Italian wine agritourism farm. Aestimum 2019, 75, 163-181. [CrossRef]

67. Canavari, M.; Centonze, R.; Nigro, G. Organic Food Marketing and Distribution in the European Union. 2007. Available online: https:/ / ageconsearch.umn.edu/record/9077 (accessed on 3 January 2022).

68. Giampietri, E.; Verneau, F.; Del Giudice, T.; Carfora, V.; Finco, A. A theory of planned behaviour perspective for investigating the role of trust in consumer purchasing decision related to short food supply chains. Food Qual. Prefer. 2018, 64, 160-166. [CrossRef]

69. Romero-Lopez, A.R.; Ramos, F.M. Understanding the linkages between small-scale producers and consumers through the analysis of short food supply chains in a local market in nopala de villagrán, Hidalgo, Mexico. Cuad. Desarro. Rural 2017, 14, 1-16. [CrossRef] 
70. Demartini, E.; Gaviglio, A.; Pirani, A. Farmers' motivation and perceived effects of participating in short food supply chains: Evidence from a North Italian survey. Agric. Econ. 2017, 63, 204-216. [CrossRef]

71. Barska, A.; Wojciechowska-Solis, J. E-Consumers and local food products: A perspective for developing online shopping for local goods in Poland. Sustainability 2020, 12, 4958. [CrossRef]

72. Venn, L.; Kneafsey, M.; Holloway, L.; Cox, R.; Dowler, E.; Tuomainen, H. Researching European "alternative" food networks: Some methodological considerations. Area 2006, 38, 248-258. [CrossRef]

73. Lioutas, E.D.; Charatsari, C. Smart farming and short food supply chains: Are they compatible? Land Use Policy 2020, $94,104541$. [CrossRef]

74. Mundler, P.; Jean-Gagnon, J. Short food supply chains, labor productivity and fair earnings: An impossible equation? Renew. Agric. Food Syst. 2020, 35, 697-709. [CrossRef]

75. Burgess, P.R.; Sunmola, F.T. Prioritising requirements of informational short food supply chain platforms using a fuzzy approach. Proced. Comput. Sci. 2021, 180, 852-861. [CrossRef]

76. Majewski, E.; Komerska, A.; Kwiatkowski, J.; Malak-Rawlikowska, A.; Was, A.; Sulewski, P.; Gola, M.; Pogodzinska, K.; Lecoeur J.L.; Tocco, B.; et al. Are short food supply chains more environmentally sustainable than long chains? A life cycle assessment (LCA) of the eco-efficiency of food chains in selected EU countries. Energies 2020, 13, 4853. [CrossRef]

77. Pitrova, J.; Kujani, K.; Molnar, J.; Kovesd, A.; Ferencz, K.S.; Trolle, A. Key competences of short food supply chain participants for creation of alternative business models. Agrarian Perspectives XXIX: Trends and challenges of agrarian sector. In Proceedings of the 29th International Scientific Conference, Prague, Czech Republic, 16-17 September 2020; pp. 279-286. Available online: https:/ / ap.pef.czu.cz/dl/88730?lang=en (accessed on 4 January 2022).

78. Wang, M.; Kumar, V.; Ruan, X.; Saad, M.; Garza-Reyes, J.A.; Kumar, A. Sustainability concerns on consumers' attitude towards short food supply chains: An empirical investigation. Oper. Manag. Res. 2021, 1-17. [CrossRef]

79. Ashtab, S.; Campbell, R. Explanatory analysis of factors influencing the support for sustainable food production and distribution systems: Results from a rural canadian community. Sustainability 2021, 13, 5324. [CrossRef]

80. Benedek, Z.; Ferto, I.; Marreiros, C.G.; De Aguiar, P.M.; Pocol, C.B.; Cechura, L.; Poder, A.; Paaso, P.; Bakucs, Z. Farm diversification as a potential success factor for small-scale farmers constrained by COVID-related lockdown. Contributions from a survey conducted in four European countries during the first wave of COVID-19. PLoS ONE 2021, 16, e0251715. [CrossRef] [PubMed]

81. Cicatiello, C. Alternative food shoppers and the "Quantity Dilemma": A study on the determinants of their purchases at alternative markets. Agric. Food Econ. 2020, 8, 15. [CrossRef]

82. Raftowicz, M.; Kalisiak-Medelska, M.; Strus, M. Redefining the supply chain model on the milicz carp market. Sustainability 2020, 12, 2934. [CrossRef]

83. Reina-Usuga, L.; de Haro-Gimenez, T.; Parra-Lopez, C. Food governance in territorial short food supply chains: Different narratives and strategies from Colombia and Spain. J. Rural Stud. 2020, 75, 237-247. [CrossRef]

84. Rivera-Ferre, M.G.; Lopez-i-Gelats, F.; Ravera, F.; Oteros-Rozas, E.; di Masso, M.; Binimelis, R.; El Bilali, H. The two-way relationship between food systems and the COVID19 pandemic: Causes and consequences. Agric. Syst. 2021, 191, 103134. [CrossRef]

85. Rosol, M.; Barbosa, R. Moving beyond direct marketing with new mediated models: Evolution of or departure from alternative food networks? Agric. Hum. Values 2021, 38, 1021-1039. [CrossRef]

86. Ruszkai, C.; Tari, I.P.; Patkós, C. Possible actors in local foodscapes? Leader action groups as short supply chain agents-A European perspective. Sustainability 2021, 13, 2080. [CrossRef]

87. Todorova, S. Short food supply chains as drivers of sustainability in rural areas. Sci. Pap. Manag. Econ. Eng. Agric. Rural Dev. 2020, 20, 483-491.

88. De Oliveira, I.K.; De Oliveira, L.K.; Lisboa, M.R.A.F.; Madalon, E.C.N.; de Freitas, L.F.; Peres Filho, A.C. The geographical distance between producers and consumers of the organic street markets: The case of Belo Horizonte, Brazil. Logistics 2021, 5, 30. [CrossRef]

89. Hanus, G. Ethnocentrism in Polish consumer food behaviour as a determinant of short supply chain development. Eur. J. Sustain. Dev. 2020, 9, 169-180. [CrossRef]

90. Joltreau, T.; Smith, A. Short versus long supply chains in agri-food sectors: Peaceful coexistence or political domination? The case of foie gras in South-West France. Sociol. Ruralis. 2020, 60, 680-697. [CrossRef]

91. Mundler, P.; Gouin, D.-M.; Laughrea, S.; Ubertino, S. Is Canada's supply management system able to accommodate the growth of farm-direct marketing? A policy analysis. J. Agric. Food Syst. Commun. Dev. 2020, 9, 261-279. [CrossRef]

92. Pulighe, G.; Lupia, F. Food first: COVID-19 outbreak and cities lockdown a booster for a wider vision on urban agriculture. Sustainability 2020, 12, 5012. [CrossRef] 